\section{JURNAL} STUDI INOVASI

e-ISSN: 2775-0922

Jurnal Studi Inovasi

Vol. 1 No. 1 (2021): 28-34

https://jurnal.studiinovasi.id/jsi

DOI:

https://doi.org/10.52000/jsi.v1i1.5

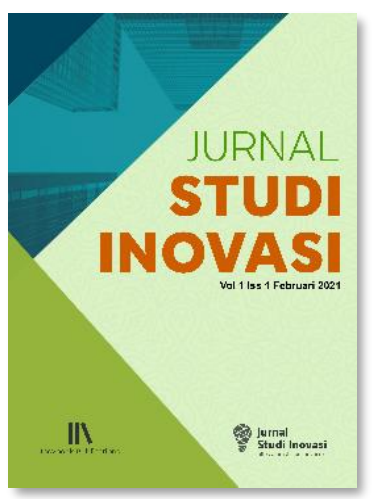

*Korespondensi

Email : yusnia.anggraini@gmail.com

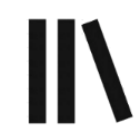

Inovbook Publications

Wisma Monex $9^{\text {th }}$ Floor

Jl. Asia Afrika No 133-137 Bandung, 40112

Karya ini dilisensikan di bawah Lisensi Internasional Creative Commons Atribusi Nonkomersial sharelike 4.0 .

\title{
Pengembangan Perizinan Kota Dengan InOVASI DaERAH STUdi KasuS PADA Kabupaten SEMARANG DAN Kabupaten Sragen Provinsi JaWA TENGAH
}

\begin{abstract}
Yusniah Anggraini
Badan Perencanaan Pembangunan Daerah Provinsi Banten | Jl. Syech Nawawi Albantani No. 1 Curug, Kota Serang, Banten 42171

Disetujui: 30 Januari 2021

Abstract

The slow process of building construction permits is a problem for the local government, this delay has a detrimental impact on the people of Semarang and Sragen regency in managing building permits. This makes the author to research and provide innovations in order to accelerate the building permit process. The method used in this research is descriptive method using qualitative analysis. With 20 respondents from each region. The results of this research innovation carried out the innovation of the Building Permit Process by telephone and Building Construction Information Systems. This innovation has a positive impact on the people who use it, being faster in the licensing process can cut the time to 7 days from the previous 14-28 days. The conclusion of this research innovation has been carried out well by the local government of the city of Semarang and the district government of Sragen.
\end{abstract}

Keywords: Licensing innovation, Technology innovation, Local government

\begin{abstract}
Abstrak
Lambatnya proses perizinan Izin Mendirikan Bangunan menjadi masalah pemerintah daerah, lambatnya ini memberikan dampak merugikan bagi masyarakat kota Semarang dan kabupaten Sragen dalam mengurus Izin Mendirikan Bangunan. Hal ini menjadikan penulis untuk meneliti sekalian mmberikan inovasi guna mempercepat proses Izin mendirikan Bangunan. Metode yang digunakan dalam penelitian ini menggunakan metode deskriptif dengan menggunakan analis kualitatif. Dengan responden berjumlah 20 dari masing-masing daerah. Hasil penelitian ini inovasi dilakukan inovasi Proses izin Mendirikan Bangunan dengan telepon dan Sistem Informasi Mendirikan Bangunan. Inovasi ini memberikan dampak positif kepada masyarakat yang menggunakannya, menjadi lebih cepat dalam proses perizinan bisa memangkas waktu jadi 7 hari dari sebelumnya sekitar 14-28 hari. Kesimpulan penelitian ini inovasi telah dilakukan dengan baik oleh pemerintah daerah kota semarang maupun kabupaten sragen.
\end{abstract}

Kata Kunci : Inovasi perizinan, Inovasi Teknologi, Pemerintah daerah 


\section{Pendahuluan}

Indonesia adalah negara berkembang, dimana membutuhkan banyak pembangunan di semua sector tak terkecuali sektor konstruksi dan bangunan. Sesuai dengan fokus pemerintahan sekarang fokus dalam pembangunan dan kontruksi menjadi pilihan utama, hal ini dikarenakan Indonesia ingin mengerjar ketertinggalan infrastruktur yang mana berguna untuk menunjang aktivitas warga Indonesia untuk menajdi negara yang makmur dan sejahtera, seiring dibutuhkan banyak pembangunan, terlihat bahwa Di beberapa tahun terakhir tingkat pertumbuhan bangunan di Indonesia semakin cepat dari tahun ke tahun, data dari Biro Pusat Statistik mengatakan bahwa rata-rata pertumbuhan konstruksi dan bangunan di Indonesia sebesar 7-8\%. Dengan pesatnya pertumbuhan ini perlu adanya aturan-aturan yang jelas, serta legalitas yang mana ketika mendirikan bangunan tidak memberikan dampak negative ke lingkungan sekitar.

Berdasarkan amanat Pasal 14 ayat (1) Undang-Undang Nomor 28 Tahun 2002 tentang Bangunan Gedung serta Pasal 14 ayat (1) Peraturan Daerah Kabupaten Semarang Nomor 2 Tahun 2015 tentang Bangunan Gedung disebutkan bahwa "Setiap orang yang akan mendirikan bangunan gedung wajib memiliki Izin Mendirikan Bangunan ". Dalam aturan tersebut, pemerintah maupun pemerintah daerah khususnya Pemerintah Daerah Kabupaten Semarang dan Sragen dengan tegas telah menekankan bahwa setiap bangunan wajib memiliki Izin Mendirikan Bangunan, bahkan aturan tersebut dilengkapi dengan ketentuan pidana bagi yang melanggar.

Akan tetapi pada kenyataan yang dihadapi saat ini, sebagian besar masyarakat hanya mengurus IMB rumah tinggalnya apabila berkaitan dengan perbankan atau dengan kata lain ketika membutuhkannya sebagai syarat dalam pengajuan pinjaman ke Bank. Tampaknya peraturan yang ada belum cukup menjadikan masyarakat menjadi patuh, sadar serta taat hukum. Hal ini dikarenakan mengurus IMB sebagai salah satu perizinan yang sangat rumit. Selain syarat administrasi yang kompleks, keterkaitan dengan banyak SKPD (misal tata ruang, kelayakan teknis bangunan dan sebagainya) membuat IMB seolah menjadi perizinan yang pasti membutuhkan waktu yang lama dan biaya pengurusan yang besar. Setiap IMB yang dikeluarkan selama ini juga belum terintegrasi dengan Geografic Information System (GIS) sehingga sulit mengontrol apakah lokasi bangunan sudah sesuai secara tata ruang.

Masalah lain yang juga terjadi di kota-kota besar, IMB sering menjadi hal yang dikeluhkan masyarakat. Keluhan tersebut muncul karena IMB kerap dijadikan sumber "penghasilan" tambahan oleh oknum-oknum tertentu. Terlebih apabila sang klien adalah suatu badan usaha, maka tarif yang dibebankan bisa sangat tinggi. Seperti yang terjadi di Kota Semarang belum lama ini, ditangkapnya seorang oknum pegawai penjaga loket yang menarik pungli IMB sebesar Rp 1 miliar kepada sebuah perusahaan pengembang. Apabila masalah tersebut tidak diatasi dikhawatirkan akan menjadi label buruk bagi pemerintah.

$$
\text { Orlandina (2015) yang }
$$

mengungkapkan bahwa dalam pembuatan IMB retribusi yang dibebankan dirasakan terlalu tinggi, jangka waktu penyelesaiannya tidak tepat waktu, birokrasi terlalu berbelitbelit, kemudian tidak sesuai dengan SOP, dan banyak terdapat pungutan liar. Keluhan atau permasalahan sebagaimana diurai di atas, Sebelum penelitian ini, telah banyak penelitian-penelitian yang juga membahas tentang IMB. Penelitian-penelitian tersebut sebagian besar membahas tentang penerapan, standar operasional dan prosedur (SOP) pembuatan IMB, serta implementasi regulasi yang mengatur IMB. Pembahasan tentang penerapan IMB dibahas di Pematang Siantar dan Sleman, oleh Sembiring (2015) dan Utami (2013).

Berbeda fokus dari kedua temuan di atas, pembahasan mengenai SOP IMB yang dilakukan di Tana Toraja dan Makassar, oleh Kameswari (2012) dan Amalia (2015) menemukan proses pembuatan IMB sudah berjalan cukup baik dan akuntabel. Dibuktikan dengan semangat kerja, loyalitas kelompok kerja, daya tanggap petugas, dan hubungan antara pimpinan dan bawahan telah terbangun dengan baik. Hal itu membuktikan pelayanan IMB sudah berjalan cukup efektif. Namun, efisiensi pelayanan dan jumlah sarana prasarana masih perlu peningkatan. Mengingat, waktu yang diperlukan untuk menyelesaikan izin masih relatif lama dan jangkauan pengawasan hanya 
pada daerah pusat saja.

Sementara itu dari sudut pandang implementasi, Erfa dan Meilani (2014) dan Irawan (2015) yang melakukan penelitian di Pekanbaru dan Malinau menemukan implementasi kebijakan IMB belum berjalan baik dan optimal. Hal ini terlihat dari sanksi yang diberikan belum maksimal dan masih banyaknya masyarakat yang tidak mau mengurus IMB

Hal inilah yang kemudian menjadikan awal ketertarikan penulis untuk membuat inovasi sebagai gagasan proyek perubahan agar minat masyarakat dan sistem inovasi yang dilakukan agar mempercepat dalam proses Ijin Mendirikan Bangunan di kota Semarang dan Sragen.

\section{Metode Penelitian}

Metode yang digunakan pada penelitian ini menggunakan metode deskriptif dengan menggunakan analis kualitatif. Metode diskriptif adalah suatu cara untuk mendiskripsikan tentang bagaimana inovasi yang digunakan dengan melakukan wawancara terhadap berbagai pihak atau responden yang memiliki kepentingan untuk dapat merealisasikan inovasi perizinan mendirikan bangunan agar tercapainya proses perizinan yang jelas, tidak ribet dan lebih cepat, ada beberapa narasumber atau responden yang menjadi objek wawancara, pada dua kota, yaitu Semarang dan Kota Sragen, narasumber tersebut meliputi masyarakat kota Semarang, masyarakat kota Sragen, Pemerintah daerah kota Semarang, Pemerintah daerah kota Sragen, Pelaku usaha yang berencana mendirkan bangunan dari kota Semarang dan kota Sragen.

\section{Hasil Dan Pembahasan}

\section{A. Inovasi Sistem Perizinan kota Semarang}

Hasil dari data deskriptif dalam penelitian dengan dilakukan wawancara beberapa narasumber yang terlibat langsung didapatkan hasil wawancara bahwa pihak dari dinas Dinas Penanaman Modal dan Pelayanan Terpadu Satu Pintu (DPMPTSP) Kabupaten Semarang merupakan Organisasi Perangkat Daerah (OPD) yang dibentuk berdasarkan Peraturan Daerah Kabupaten Semarang Nomor 19 Tahun 2008 sebagaimana diubah dengan Peraturan
Daerah Kabupaten Semarang Nomor 11 Tahun 2013 tentang SOTK Badan Perencanaan Pembangunan Daerah, Inspektorat, Lembaga Teknis Daerah dan Kantor Pelayanan Perizinan Terpadu Kabupaten Semarang, dengan tugas pokok melaksanakan penyusunan dan pelaksanaan kebijakan daerah di bidang penanaman modal dan perizinan terpadu (Perda, kota Semarang).

Dikarenakan kebutuhan yang mendesak untuk mempercepat proses pembangunan pihak pemerintah daerah merujuk pada peraturan daerah kabupaten semarang nomor 19 tahun 2008 maka, dibentuklah sistem PRIMBON (Proses Ijin Mendirikan Bangunan dengan Telepon) dengan bermodalkan telepon inovasi PRIMBON ini menghubungkan kebutuhan masyarakat agar tidak perlu mengantri di dinas penanaman modal dan pelayanan perizinan. Dan juga masyarakat akan didatangi oleh perwakilan dari dinas penanaman modal dan pelayanan perizinan ke rumah masyarakat yang telah menelepon kedinasan.

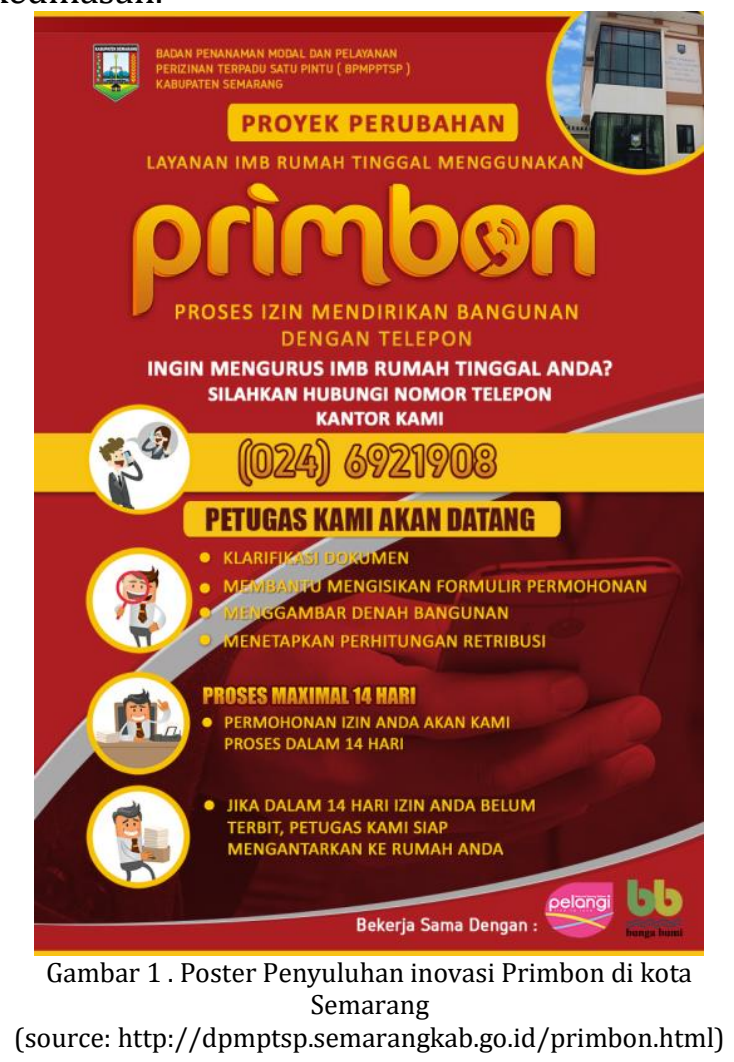

Dari gambar 1 terlihat bagaimana upaya pemerintah daerah untuk mengenalkan sistem inovasi proses izin mendirikan bangunan menggunakan telepon kepada masyarakat umum. Terlihat dengan informasi yang diberikan oleh pemerintah daerah untuk yang 
cukup mudah dipahami bagi masyarakat umum. Hal ini termasuk komitmen pemerintah untuk mempercepat proses perizinan yang terkenal beribet. Dengan sering-sering mengenalkan inovasi proses izin mendirikan bangunan menggunakan telepon, diharapkan masyarakat umum khususnya para pengusaha yang ingin membangun bangunan untuk berinvestasi dapat lebih mudah dan cepat dari sistem perizinan sebelumnya.

\section{B. Inovasi Sistem Perizinan Bangunan Kota Sragen}

Di kota sragen, mengacu pada peraturan pemerintah untuk meningkatkan kualitas layanan publik, maka pemerintah telah mengesahkan Undang-undang Nomor 25 Tahun 2009 tentang Pelayanan Publik. Dalam Undang-undang tersebut, diharapkan pemerintah mampu melayani setiap warga Negara untuk memenuhi hak dan kebutuhan dasarnya dalam rangka pelayanan publik, memberikan kepastian hukum dalam hubungan antara masyarakat dan penyelenggara pelayanan publik. Di sisi lain, perkembangan Teknologi Informasi dan Komunikasi telah merambah pada berbagai bidang kehidupan dan tidak dapat dipungkiri bahwa Telematika dapat membantu peningkatan efektivitas dan efisiensi kerja dari suatu organisasi.

Dengan ini maka pemerintah daerah Sragen berupaya untuk memperdayakan telematika adalah melalui percepatan pengembangan e-government. Implementasinya adalah membangun pelayanan perijinan yang terpadu. Pemerintah Kabupaten Sragen telah melakukan perubahan mendasar pada bidang pelayanan, yaitu melakukan proses transformasi menuju pelayanan administrasi berbasis teknologi informasi, atau mengembangkan Sistem Informasi Manajemen Ijin Mendirikan Bangunan (SIM-IMB) berbasis GIS. Hal ini dikarenakan Pengembangan Aplikasi SIM-IMB berbasis GIS merupakan upaya untuk mengembangkan penyelenggaraan pemerintahan berbasis elektronik (eGovernment) dalam rangka meningkatkan kualitas pelayanan publik yang efektif, efisien, dan transparan, serta diarahkan untuk mencapai pembentukan jaringan informasi dan transaksi pelayanan publik yang berkualitas tanpa dibatasi sekat ruang dan waktu. Tujuan akhirnya adalah Program Aplikasi SIM-IMB berbasis GIS ini diharapkan mampu mengakomodir perencanaan pelayanan IMB, hakekat dan sifat Pelayanan Prima (Excellent service). Sehingga mendorong terwujudnya pelayanan perizinan yang terpadu atau menuju layanan "One Stop Service".

Untuk menunjang kegiatan tersebut perlu suatu aplikasi IMB yang memudahkan petugas IMB pada Dinas Perumahan Dan Kawasan Permukiman dalam melakukan pendataan pemohon IMB baik dalam melakukan rekapitulasi pemohon IMB per kecamatan atau per desa, kesesuaian dengan tata ruang, dan kesesuaian gambar teknis. Aplikasi tersebut dapat dilakukan secara online hal ini untuk memudahkan masyarakat yang ingin mendaftarkan Izin Mendaftarkan bangunan daripada dengan cara lama terkesan rumit dan membutuhkan waktu yang lama karena harus mengikuti prosedur. Dengan inovasi ini data dapat terinput langsung ke sistem sehingga pegawai dari kedinasan yang menangani perizinan dapat langsung melihat dan menindak lanjuti dokumen-dokumen yang diberikan dari masyarakat yang ingin mengurus Izin Mendirikan Bangunan.

Sistem aplikasi SIM-IMB berbasis GIS ini telah dilakukan evaluasi secara mendalam dari pihak internal dan akhirnya dikembangkan untuk mengakomodasi semua sistem perizinan di satu aplikasi, hal ini agar dapat menjadi one gate sistem, yang mana dapat memenuhi keperluan masyarakat tentang semua hal yang berhubungan dengan perizinan di seluruh kabupaten Sragen

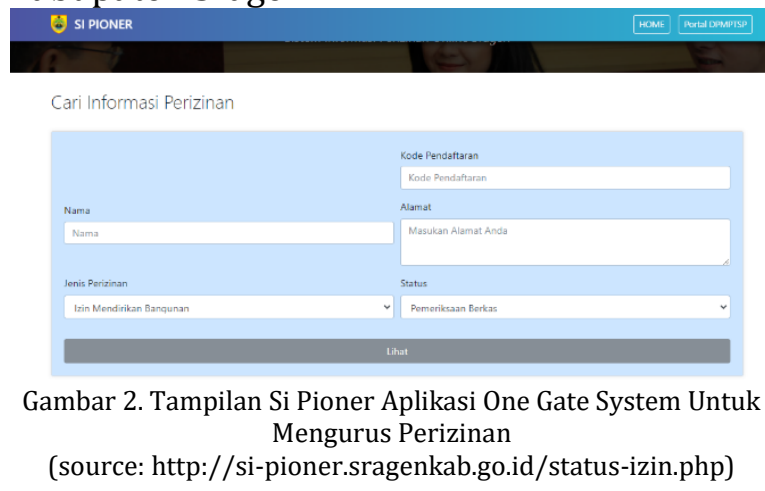

Berdasarkan gambar 2. Terlihat bahwa aplikasi online tersebut terdapat lima item yang harus di isi, pertama ada nama, nama disini sebagai nama calon pengurus perizinan, kedua ada kode pendaftaran adalah urutan 
pendaftaran masyarakat, kemudian ada alamat, alamat ini di isi lokasi pendaftar dimana, kemudian ada jenis perizinan, jenis perizinan ini terdapat macam 2 jenis perizinan yang dibutuhkan pendaftar, pendaftar hanya tinggal memilih perizinan seperti apa yang dibutuhkan, di opsional ada semua, dan yang terakhir ada status pendaftar, di opsional ini pendaftar diberi lima opsional yaitu, semua, pemeriksaan berkas, proses perizinan, pemeriksaan lapangan, dan selesai. Tiap opsional punya fungsi masing-masing, sesuai tahapan pendaftar yang diajukan. Dari lima item diatas sudah mewakili informasi yang dibutuhkan pegawai. Sehingga proses pendaftaran bisa lebih cepat.

\section{Persepsi Masyarakat Terhadap Inovasi di Kota Semarang dan Kabupaten Sragen}

Hasil wawancara dengan 20 masyaraka sebagai calon pendafatar perizinan dari masing-masing kota Semarang dan kabupaten Sragen, terlihat bahwa $80 \%$ dari total keseluruhan narasumber ketika di wawancarai merasa terbantu dan lebih mudah dalam mengurus perizinan Mendirikan Bangunan, hal ini dikarenakan kedua inovasi tersebut memberikan dampak percepatan pengurusan dari masing-masing daerah, seperti inovasi yang ada di kota Semarang masyarakat yang ingin mengurus perizinan merasa special hal ini juga pengurus perizinan hanya menggunakan telepon untuk meminta perizinan Mendirikan Bangunan dan tim dari kedinasan akan datang ke rumah masyarakat yang telah menelepon untuk mengurus Perizinan Mendirikan Bangunan untuk mengurus berkasnya, tanpa harus mengantri panjang di kantor pengurusan. Begitu juga hasil wawancara dengan masyarakat Kabupaten Sragen terhadap inovasi pengurusan perizinan mendirikan bangunan online, inovasi tersebut dikatakan praktis oleh masyarakat, dengan adanya inovasi seperti ini masyarakat dapat menghemat waktu untuk masalah perizinan bisa sampai astu minggu sampai jadi. Ini jadi keuntungan tersendiri bagi masyarakat, untuk dapat segera melakukan tahap pembangunan.

\section{Strategi Pemerintah Daerah Kota Semarang dan Kabupaten Sragen Agar Inovasi Dikenal Masyarakat}

Pemerintah daerah kota Semarang dan kabupaten Sragen melakukan pengenalan inovasi Proses Perizinan Mendirikan Bangunan dengan Telepon dan sistem Informasi Mendirikan Bangunan dengan memberikan penyuluhan ke pendaftar yang datang ke kantor untuk dapat melakukan pengalihan proses Perizinan dengan mekanisme tersebut, serta membuat banner-banner di berbagai sudut kota Semarang dan kabupaten Sragen. Hal ini untuk dapat menjangkau masyarakat umum lebih luas agar dapat mengetahui untuk proses Perizinan Mendirikan Bangunan bisa lebih cepat dari sistem sebelumnya.

Pemerintah juga melakukan pengiklanan di media sosial karena di jaman sekarang mengiklankan menggunakan media sosial lebih mudah tepat sasaran karena kebiasan masyarakat yang tidak lepas dari gadget.

Cara-cara tersebut terbukti efektif untuk mengenalkan inovasi mereka ke masyarakat umum hal ini tidak lepas dari semua pihak baik kedinasan maupun tim support untuk mensukseskan mengenalkan inovasi tersebut ke masyarakat umum.

\section{E. Keuntungan Penggunaan Sistem inovasi Proses Perizinan Mendirikan Bangunan dengan Telepon dan sistem Informasi Mendirikan Bangunan}

Dengan adanya Sistem inovasi Proses Perizinan Mendirikan Bangunan dengan Telepon dan sistem Informasi Mendirikan Bangunan terdapat beberapa keuntungan.

Pertama, keuntungan dalam bidang biaya dan waktu, hal ini dikarenakan inovasi dalam IMB yang dilakukan oleh DPMPTSP Kota Semarang melalui program PRIMBON telah memangkas waktu pembuatan IMB menjadi hanya 7 hari kerja dari yang semula 14 sampai 28 hari kerja. Kecepatan pelayanan faktor yang sangat dekat dengan kepuasan penerima layanan (Pratama, 2013). Karena pada umumnya kecepatan layanan menjadi fitur eksklusif yang bisa didapatkan dengan mengeluarkan biaya yang lebih besar. Namun pada inovasi IMB di Kota Semarang masyarakat bisa mendapatkan layanan yang cepat tanpa perlu mengeluarkan biaya 
ekstra. Biaya pengurusan juga menjadi lebih rendah sejak diterapkannya layanan online. Penurunan biaya ini karena pemohon hanya perlu menyerahkan persyaratan pada tahap awal dan berikutnya telah tersimpan di data base dinas. Faktor efisiensi waktu ini sesuai dengan pengertian inovasi yang dikemukakan oleh Mulgan dan Albury dalam Khairul Muluk (2008), Inovasi merupakan kreasi dari proses, produk pelayanan dan metode pelayanan baru yang merupakan hasil dari efisiensi, efektivitas, atau kualitas hasil.Apalagi dengan adanya program IMB Jemput Bola, pembuatan IMB menjadi lebih efisien. Karena masyarakat hanya perlu pergi ke titik layanan IMB Jemput Bola berada kemudian membuatnya di tempat tersebut. Sehingga masyarakat sekitar bisa sangat menghemat waktu dan biaya.

Kedua, Ketepatan waktu Program PRIMBON merupakan salah satu program yang dibuat untuk meningkatkan kualitas layanan IMB Pemutihan dan menarik minat masyarakat untuk segera membuat IMB. Dalam pelaksanaannya program ini bisa diwujudkan tepat waktu sesuai dengan namanya. Namun ketepatan tersebut dapat dicapai dengan catatan, berkas permohonan dan persyaratan yang dibutuhkan dapat langsung diproses dan tidak bermasalah. Hal tersebut bisa mempengaruhi ketepatan waktu dari program tersebut. Untuk itu diharapkan kepada masyarakat yang ingin membuat IMB supaya mengecek kembali kelengkapan berkas dan persyaratan.

Ketiga, Melalui inovasi juga, masyarakat semakin dimudahkan dengan adanya beberapa perubahan pada persyaratan pembuatan IMB. Untuk IMB Pemutihan sendiri persyaratan yang ditentukan sangat fleksibel dan mempermudah pemohon. Seperti sketsa bangunan yang disyaratkan tidak memerlukan software khusus melainkan gambar tangan saja. Pemohon juga bisa bertanya kepada petugas loket apabila mengalami kesulitan dalam menggambar. Inovasi tersebut sangat memudahkan masyarakat dibanding harus mengeluarkan biaya tambahan untuk menyewa jasa penggambar apabila jasa itu diperlukan.

\section{F. Faktor Penghambat Inovasi Penggunaan Sistem inovasi Proses Perizinan Mendirikan Bangunan dengan Telepon dan sistem Informasi Mendirikan Bangunan}

Pertama, Layanan yang dibutuhkan untuk Sistem Online di Kabupaten Sragen membutuhkan kondisi jaringan yang stabil untuk mendukung proses pembuatan IMB. Bahkan, mulai dari proses registrasi sampai dengan cek status perizinan sudah menerapkan sistem online tersebut. Hal ini tentu saja merupakan kemajuan yang sangat positif dalam perizinan IMB di Kabupaten Sragen. Namun penerapan online tidak dapat dipastikan selalu berjalan mulus. Ada kalanya server mengalami gangguan yang menyebabkan koneksi internet terputus. Apabila hal tersebut terjadi tentu saja akan mengganggu proses pembuatan IMB yang sedang berlangsung.

Kedua, Sumber Daya Manusia (SDM) yang dibutuhkan IMB adalah izin yang mengatur bagaimana sebuah bangunan seharusnya berdiri dari sisi teknis sekaligus administrasi sesuai Perda Bangunan Gedung. Untuk melaksanakannya diperlukan tenaga yang memiliki keilmuan dalam teknis bangunan. Tim yang dibuat untuk melaksanakan inovasi jemput bola seharusnya juga memiliki kompetensi serupa. Tetapi dengan pemusatan tugas seperti di atas terdapat kecenderungan bahwa pelaksanaan inovasi IMB akan bergantung pada tim yang bertugas. Apabila terjadi demikian saat ada salah satu dari tim tersebut yang berhalangan proses pembuatan IMB akan berjalan tidak maksimal. Tentunya hal tersebut akan kembali berakibat pada ketidakpuasan masyarakat.

Ketiga, Sarana Pendukung untuk menerapkan kedua inovasi ini inovasi IMB Pemutihan dengan metode telepon dan sistem online dan memerlukan sarana dan prasarana yang mendukung pelaksanaannya. Dalam hal ini, pemerintah daerah yang mengurus perizinan Kota Semarang dan kabupaten Sragen telah membentuk tim yang bertugas pada titik-titik dimana pemilik IMBnya masih kurang. Pembentukan tim ini didukung dengan sarana penunjang operasional selama mereka melakukan pelayanan IMB jemput bola dan sistem online. 
Namun untuk saat ini sarana dan prasarana yang ada hanya satu satu mobil operasional dan satu set komputer untuk membuat IMB. Satu perangkat tersebut masih dirasa kurang karena hanya mampu menjangkau satu titik dalam satu hari. Belum lagi jika mobil atau komputernya bermasala

\section{Kesimpulan Dan SARAN}

Berdasarkan hasil penelitian dapat disimpulkan bahwa Inovasi yang dilakukan di kota Semarang dan kabupaten Sragen telah dilakukan dengan baik, kesmipulan ini berdasar pada perizinan dan observasi yang dilakukan penulis Dari observasi dan pengamatan tersebut penulis lalu menguraikan prosedur pembuatan, kemudian berbagai inovasi yang dilakukan dinas, serta keuntungan inovasi dan faktor yang menghambat pelaksanaan inovasi tersebut. Diharapkan dengan mengidentifikasi hal tersebut di atas turut meningkatkan kualitas dan kecepatan pelayanan perizinan IMB di Kota Semarang dan kabupaten Sragen.

Saran untuk pemerintah daerah kota Semarang dan kabupaten Sragen agar selalu melakukan evaluasi berjangka, hal ini bertujuan agar inovasi tersebut dapat berfungsi dengan semestinya sehingga dapat tercapai dalam mempercepat proses perizinan mendirikan bangunan, kemudian untuk peneliti selanjutnya dpat dilakukan di kotakota yang terpelosok dengan sistem yang kurang memadai, agar tau masalah apa yang menghambat perizinan disana

\section{UCAPAN TERIMA KASIH}

Terima kasih disampaikan penulis kepada DPMPTSP Kota Semarang, DPMPTSP kabupaten Gresik, kepala tata ruang kota Semarang,kepala tata ruang kabupaten Sragen, Masyarakat dari kedua kota yang akan mengurus IMB, pembuat sistem Aplikasi, dan semua pihak yang terlibat tidak dapat disebutkan satu persatu yang telah memberikan masukan agar artikel ini dapat menjadi lebih baik

\section{Daftar Pustaka}

Andi Irawan. (2015). Implementasi Peraturan Daerah Nomor 5 Tahun 2001 Tentang Izin Mendirikan
Bangunan di Kecamatan Malinau

Kota Kabupaten Malinau.

Dinas Penanaman Modal dan Pelayanan Terpadu Satu Pintu (DPMPTSP), Semarang

Dinas Penanaman Modal dan Pelayanan Terpadu Satu Pintu (DPMPTSP), Sragen

Erfa, R. E. M., \& Meilani, N. L. (2014). Implementasi Retribusi Izin Mendirikan Bangunan. Jurnal Administrasi Pembangunan, 2(3), 293-298.

Khairul Muluk. (2008). Knowledge Management: Kunci Sukses Inovasi Pemerintahan Daerah. Malang: Bayumedia.

Mareci Susi Afrisca Sembiring. (2015). Efektivitas Advis Planning dalam Pelayanan Izin Mendirikan Bangunan Di Kota Pematangsiantar. E-Journal UAJY.

Norma Vita Utami. (2013). Pelayanan Permohonan Izin Mendirikan Bangunan Di Kabupaten Sleman (Perda No. 5 Tahun 2011 Tentang Bangunan Gedung). UIN Sunan Kalijaga Yogyakarta.

Nurul Amalia. (2015). Akuntabilitas

Pelayanan Izin Mendirikan

Bangunan(IMB) Di Badan Perizinan

Terpadu dan Penanaman Modal Kota

Makassar. Universitas Hasanuddin

Makassar.

Rizki Pratama. (2013). Inovasi Pelayanan

Publik (Studi Deskriptif Tentang Nilai

Tambah (Value Added) Inovasi

Pelayanan Perizinan Bagi Masyarakat

Di Kota Kediri). Kebijakan Dan

Manajemen Publik, 1(2)

Septi Orlandina. (2015). Pelayanan Pembuatan Surat Izin Mendirikan Bangunan Di Badan Pelayanan Perizinan Terpadu (BP2T) Kota Pontianak. PublikA, Jurnal Ilmu Administrasi Negara, 4(3). 